\title{
Teaching Sociolegal Research Methodology: Participant Observation
}

\author{
Special Issue on Active Learning and Teaching in Legal Education \\ Bart van Klink, Hedwig van Rossum \& Bald de Vries (eds.)
}

Marc Simon Thomas*

\section{Introduction}

The basics of how to conduct participant observation are not taught in law schools. This is striking because this methodology has become a common feature of qualitative research and could be very useful in sociolegal research. For those interested in studying 'law in practice' instead of 'law in the books', qualitative research methods like participant observation are inevitable. However, participant observation is, at best, secondary in the literature on qualitative research in the sociolegal discipline. In The Oxford Handbook of Empirical Legal Research (Cane \& Kritzer, 2010), for example, participant observation is mentioned only in Chapter 38, where it is presented as a particular way to observe (Webley, 2010, pp. 937-938). In the undergraduate program at Utrecht University School of Law, we prescribe Research Skills. Instruction for Lawyers by Ian Curry-Sumner, Kirsten, Van der Linden-Smith, and Tigchelaar (2010), a book on basic research skills for lawyers that is basically about written primary and secondary legal sources. That work employs something of a classic doctrinal approach, which concerns the construction, evaluation and reform of laws and legal concepts on the basis of an analysis of authoritative legal sources (e.g. legislation, case law) and academic legal literature. It provides legal scholars with no more than an 'internal' legal approach, meaning that they are taught to consider their subject from the point of view of professionals who engage in it (e.g. legislators and judges). In the few instances in which sociolegal research is mentioned, reference is made only to observations and interviews (Curry-Sumner et al., 2010, pp. 6-7). In fact, students are discouraged from conducting empirical legal research themselves, as the authors state: 'Due to the fact that many legal academics and aspiring legal academics do not usually possess the skills required for conducting this sort of research, they normally rely on research already conducted by social scientists' (Curry-Sumner et al., 2010, p. 23). An exception can be found in the book Law and Method (Van Klink \& Taekema, 2011), where participant observation is positively

* Utrecht University, School of Law, Institute of Jurisprudence, Constitutional and Administrative Law, Legal Theory; m.a.simonthomas@uu.nl 
treated as a way to 'study research topics that are broad, ambiguous and poorly defined' (Van Aeken, 2011, p. 79). However, there is absolutely no guidance on how to conduct this technique.

This is interesting because, in my experience, both Bachelor's and Master's students are increasingly interested in doing empirical legal research. Two $\mathrm{PhD}$ candidates that I am currently co-supervising make use of empirical qualitative research methods. And recently two dissertations involving the prominent use of participant observation were successfully defended in the Netherlands (Holvast, 2017; Lindeman, 2017). Holvast did research on the role of judicial assistants in courts and their role in relation to judges. She discusses the involvement of judicial assistants in judicial decision-making and the potential consequences of their involvement in the adjudication process. Lindeman studied the daily work of Dutch public prosecutors. To say that a judge has authority (Holvast, 2017) or that public prosecutors 'have always enjoyed a special position' (Lindeman, 2017, p. 295) is conveying information but really provides no meaningful data unless we can specify the information in question. Both cases refer to the power or control these individuals have in their professional roles. But to be able to give such a characterization in the first place requires all kinds of data that are the product of participant observation (Moore \& Sanders, 2006, pp. 159-160).

Participant observation is often considered the primary method of anthropology, tracing its roots to Bronislaw Malinowski (1985 [1926]) as the founding father of fieldwork. In recent decades, however, participant observation has become a common feature of qualitative research in a number of disciplines (DeWalt \& DeWalt, 2002, p. vii; Friedrich \& Lüdtke, 1975, pp. 7-12; Jorgensen, 1989; Zaitch, Mortelmans \& Decorte, 2010). This includes the sociology of law, as this article will show. This is because participant observation provides for the possibility that the researcher has neglected crucial questions, which otherwise would not be asked - 'not out of stupidity or laziness, but because he or she did not know they were there to be asked' (Toren, 2006, p. 215). The method of participant observation means that the researcher takes part in the social setting that is under study. Participant observation is best understood as 'being there'. And while 'being there', the researcher obtains information through relatively intense, prolonged interaction with those persons being studied and first-hand involvement in the relevant activities of their lives. The techniques that are used are observation, listening, collecting things and personal experience, all written down in field notes. The researcher has less control during participant observation than in other qualitative methods (e.g. observation or interviews). This is because a participant observer takes part in many of the events and processes he or she is observing, in order to try to better understand them. The researcher is reacting to and interacting with others in those events and processes that unfold before him or her. This is done in order to better understand why those being studied find these events and processes meaningful, as well as to see how the processes 
in question are organized and conducted (DeWalt \& DeWalt, 2002, p. vii; Kottak, 2002, pp. 35-36; Levine, Gallimore, Weisner \& Turner, 1980).

Although participant observation has become a common feature of qualitative research, there is surprisingly little literature on how to teach this topic. For a long time, the 'sink or swim' approach was considered the only way to learn how to do fieldwork (Levine, Gallimore, Weisner \& Turner, 1980; Wallace, 1999, p. 210). In a volume for anthropologists, edited by Sanjek (1990), for example, several authors confirm that they did not receive any training in how to write field notes (Jackson, 1990; Sanjek, 1990). Rabinow (2007, p. 4) writes: 'as graduates we are told that "anthropology [i.e. fieldwork] equals experience"'. To my knowledge, only an article by Levine et al. (1980) provides an in-depth description of how participant observation can be taught (i.e. through a combination of both structured in-class exercises and discussion, and actual field experiences). By combining exercises and fieldwork, the instructors are provided with an opportunity to closely supervise students' practice of skills that they have learned. Both classroom lessons and experiences in the 'real' field provide the tools to teach basic skills in research design, data collection, and data analysis (Levine, Gallimore, Weisner \& Turner, 1980, p. 40). From that perspective, it is interesting to refer to an article by Rasch, Simon Thomas, Cremers, and Verschuuren (forthcoming), where the different dimensions of students' first fieldwork experiences (including participant observation) are examined in detail.

This article is written with two audiences in mind. It should serve as a useful reference and guide for those who teach qualitative research methods in legal education and who are looking to enhance their knowledge and skills concerning participant observation. It is also meant to serve as a basic primer for the beginning sociolegal researcher who is about to become a participating observer for the first time. To achieve that result, this article is structured in a straightforward manner. The following section will explain what participant observation consists of. First, it identifies the key elements of participation and then discusses participation, observation, and the different types of participant observation, concluding with some remarks on the use of this method. The second section discusses the different experiences I had with learning, conducting, and teaching participation in order to set the stage for presenting an example of how participation can be taught in Sociology of Law courses (i.e. involving 'playing musical chairs') in the third section.

\section{Participant observation}

'Participant observation is a method in which a researcher takes part in the daily activities, rituals, interactions, and events of a group of people as one of the means of learning the explicit and tacit aspects of their life routines and their culture', as the definition of DeWalt and DeWalt (2002, p. 1) states. Basically, participant 
observation has two purposes (Spradley, 1980, p. 54). In addition to engaging in relevant activities, participant observation involves the observation of people, their activities, and the environments in which they function. Participant observation being a method, or perhaps a technique presumes a research question which can be best answered by using this particular method (Van Aeken, 2011, p. 78). In other words, if one wants to get to know how and why people behave the way they do (i.e. 'the explicit and tacit aspects of their life routines') (Spradley, 1980, p. 7), ${ }^{1}$ from an insider's perspective, participant observation is the method of choice (Zaitch et al., 2010). Observing or interviewing (or even archival and literature research) can also provide empirical, qualitative data. However, without the aspect of participation, such methods necessarily involve some distance between the researcher and his informants. A researcher who does nothing more than observe and interview remains something of a fly on the wall. Participant observation affords the researcher the opportunity to become - if you will - 'a fly in the soup'. When conducting participant observation, the insider's perspective is not merely observed and questioned; it is also directly experienced.

The key elements of participant observation as a method to gather empirical and qualitative data are as follows. As a participant observer, the researcher participates (e.g. works in or lives in) the context of the research for a longer period. For example, if research is done among judges, ideally, the researcher has a desk at the court for at least a couple of months. The researcher learns and uses office language and legal jargon, attends as many hearings as possible, is present at meetings, joins the judges for lunch, and also goes to social gatherings In other words, he or she participates in a wide range of routine and special activities and events with his or her informants (DeWalt \& DeWalt, 2002, p. 4) and observes during such participation. During these actions, the researcher also uses everyday conversation as an informal interview technique (Baarda, De Goede \& Van der Meer-Middelburg, 1996; DeWalt \& DeWalt, 2002, pp. 120-140). A participant observer becomes an expert in 'hanging out' (i.e. informally observing during leisure activities). He or she records observations in field notes (Spradley, 1980, p. 58; see also the third section of this paper) and analyzes both explicit and tacit information. Besides participating, observing, and conversing, the researcher finds valuable data in documents (like journals or letters), other forms of communication (e.g. social media), and objects both big and small (e.g. clothing or buildings) (Jorgensen, 1989, p. 22; Zaitch et al., 2010, pp. 273-274). If done in a proper way, participant observation enhances the quality of data collection and the quality of the interpretation of the data. Participant observation thus serves as a tool for both data collection and data analysis.

1 The 'explicit' aspects of their daily routines constitute part of what people are able to articulate about themselves, ".... level of knowledge people can communicate about with relative ease" (Spradley, 1980, p. 7). In contrast, people are unaware of the 'tacit' aspects of their daily routines. 


\subsection{Participation}

Becoming a successful participant involves a number of practical processes. First, to state the obvious, one has to gain entrance to the research setting (DeWalt \& DeWalt, 2002, pp. 35-37; Zaitch et al., 2010, pp. 392-396). For this purpose, formal clearance to the research setting may need to be secured. For example, doing research at a public prosecutor's office or in courts requires prior permission. This often involves filling out forms, explaining the goals of the research, estimating the impact on the informants, and so on. But most importantly, getting formal permission takes time and is not guaranteed. Informal clearance is another thing. After taking care of formal issues, the next step is to identify someone who can provide you with a good introduction in the actual research setting. At an office or a court, this might be a manager or a senior judge who provides you with a general orientation on your first day of fieldwork. However, to really get access to relevant meetings, lunches, or social gatherings, one often needs the help of a more informal leader. Institutions like a public prosecutor's office or a court do have a formal hierarchy but, more often than not, there is an 'informal hierarchy' as well. It takes some time to identify the gatekeepers who will facilitate your entrée into the research setting.

Once 'in the field', the researcher must pass through several stages. The stage of first contact is one of getting to know as many people as possible. This presumes an open and curious attitude on the part of the researcher. On the other hand, the people you are studying are often as curious about you as you are about them. This means one has to be prepared to answer questions about the ins and outs of research, its goals, and its methodology. In addition, one must be prepared for more personal questions - and also for questions of an opportunistic nature (e.g. 'If I help you, what's in it for me?'). The second stage involves 'establishing rapport' (Kottak, 2002, p. 35). This is an essential element of participant observation, since the existence of trust and cooperation provides the opportunity to get a 'real' understanding of daily life. As in any relationship, rapport between persons is something that is built over the course of time (DeWalt \& DeWalt, 2002, p. 40).

Building rapport is necessary for gaining acceptance within the group of study. You need to show that the relationship that is built is important to you. Taking things as seriously as your informants do is essential to gaining acceptance. Participation also requires being able to communicate in an effective way in the research setting. In a legal setting, this means learning and using professional legal language. But it also means that you are able to follow informal conversations, to understand and appreciate jokes, etc. (DeWalt \& DeWalt, 2002, p. 48). The core of participant observation, however, is to behave appropriately enough to be accepted as a participant and to take part in the daily activities of your informants. Fortunately, learning how to behave appropriately is not very hard. It should be relatively easy to pick up the manners of the people you work with (DeWalt \& DeWalt, 2002, p. 50). Two important suggestions in this regard: do not 
be too shy, and do not be afraid to make mistakes. Making mistakes provides your informants with the opportunity to correct you by explaining what is appropriate and why. This provides you with an excellent opportunity to learn how to behave like your informants do and to ask further questions. This is an opportunity you probably would not have had if things had gone off without a hitch. 'Talking the talk and walking the walk' is at the heart of participant observation. But here too, it is important to be patient: gaining acceptance does take time.

\subsection{Observation}

Conducting participant observation is obviously not only about participating, but also about observing. Without being a good observer, the method of participant observation will not help you much as a research tool. Observation as such is a method effectively used in courtrooms (Doornbos, 2014; Van Rossum, 1998). Essentially, observing (i.e. as a research methodology) means that the researcher is explicitly and self-consciously attentive to the events and people in the context he is studying, for the purpose of systematically recording what he sees. Observing is not just a visual phenomenon but includes all of the senses, including hearing. Participant observation also includes self-observation, which refers to researchers' attentiveness to their own experience of participant observation, including any biases that they might have. This self-observation also includes reflection on the part of researchers as to their own possible impact on the research setting (DeWalt \& DeWalt, 2002, p. 68). It can be seen here that, as mentioned earlier, participant observation is a tool for both data collection and data analysis.

Probably the most important skill a participant observer needs to develop is the ability to observe details. Effective observing, as DeWalt and DeWalt (2002, p. 69) emphasize, is 'seeing' every situation as fully as possible. 'Seeing' can, in this context, include the details and the arrangement of a physical space, the actors in that space, and the activities that take place. Such fine-tuned observation is not an easy task, although it can be learned. Observational techniques that can be used include: mapping the scene (drawing a map of the place, positioning the people in that space, noting movements, etc.), counting (how many of what kind of people are there, how many of them are doing what, proportion of men to women, adults to children, etc.), looking at or counting of things (e.g. text-based artifacts or physical objects), or attending to conversations (listening). An important aspect of observation is taking notes (ideally, based on a topic list) and writing more comprehensive field notes afterwards.

An obvious question here involves what, exactly, is to be observed. As DeWalt and DeWalt (2002, p. 76) write, most observations that are recorded in notebooks consist of everyday, frequently repeated events. Observation concerns mainly patterned behaviors. Thus, the researcher will for the most part be observing the daily, weekly, and monthly activities (i.e. particular patterns of repetitive behavior), on the one hand, while, of course, also noting the unpredicted and unusual events that take place against the backdrop of these routine actions. A participant 
observer should observe daily activities in order to construct and understand the 'storyline', while at the same time looking for variations and exceptions within that storyline (which may reflect differences in status or position). There are obviously limitations as to what one can reasonably observe. It is impossible to observe everything. That is why it is important to always keep one's research question in mind. In general, one starts by trying to observe and record everything that is new, but after a while more attention can be paid to what falls within the scope of the actual research. For example, when I conducted research on local forms of dispute settlement in the Ecuadorian highlands, I started by researching the daily life of the people to get a better understanding of their specific disputes.

\subsection{Types of participant observation}

It is obvious that participant observation combines two different processes, and thus, as a method, it should be distinguished from both pure observation and pure participation. Pure observation aims to keep the researcher away from contact with his or her informants and the latter's activities, so as to avoid their influence. Pure participation, on the other hand, can be described as 'going native'. In such an instance, the researcher sheds his or her identity as a researcher altogether and instead embraces the identity of a full participant in the social setting being studied (DeWalt \& DeWalt, 2002 p. 18). The ethnographer James Spradley (1980, pp. 58-62) has developed a typology that describes the following continuum in the 'degree' of participation of researchers: 1) non-participation, 2) passive participation, 3) moderate participation, 4) active participation, and 5) complete participation.

For Spradley, non-participation essentially amounts to pure observation, given that no participation takes place. Non-participation occurs when data are collected by observing activities from outside the research setting, for example by watching television or reading newspapers or by viewing a video transmission (live or taped) of court proceedings. In 'passive observation', the researcher is present in the scenario being studied but does not participate or interact with the people or actions he or she observes. This is what Doornbos (2014) describes in her article on observations in the courtroom. The only 'role' the researcher has is that of spectator. Moderate participation occurs when the researcher is present within the setting being studied and can be identified as a researcher but does not actively participate or interact. This is what Spradley (1980, p. 60) describes as 'a balance between insider and outsider, between participation and observation'. Active participation involves the researcher actually engaging in almost everything that his informants are doing as a means of trying to get the insider's perspective, while still retaining his or her identity as a researcher. Complete participation means that the researcher becomes a member of the group that is being studied (e.g. by getting a job at the public prosecutor's office or at a court). As I explain to my students, if you want to do research on the work and lives of taxi drivers, get a driver's license and become one yourself. It should be noted that complete participation is not the same as 'going native' because, in the former 
instance the role assumed is temporary and the researcher continues to function as an investigator (DeWalt \& DeWalt, 2002, p. 21).

The level of involvement of the researcher has implications for the control over the situation and the kind of data that can be obtained. The less active the participation is, the more control the researcher has. In a situation of non-participation or passive participation, no interviews can be conducted. Therefore, in such scenarios, the researcher is unable to build rapport or to ask questions as new information becomes available. No real insider's perspective can be experienced, but the control over one's own role is secured. During moderate participation, active participation, or complete participation the researcher progressively takes on the role of 'the fly in the soup'. This more active role secures access to more comprehensive data, while giving the researcher less control over the situation. Obviously, Spradley identifies degrees of participation as a kind of 'ideal type', in the sense of Max Weber. An individual researcher can fall anywhere along the continuum. The point is that the researcher should be aware of the differences in access to the research setting, in the data that can be obtained, and the relative degree of objectivity and subjectivity of what exists at any point along the continuum (DeWalt \& DeWalt, 2002, p. 23).

\subsection{Some additional comments}

It is clear that there are some limitations to the use of participant observation. As mentioned previously, one needs, first and foremost, to get access to the field of research - both formally and informally. Participant observation is also time-consuming. It takes time to get access, to build rapport, to get accepted, and then, of course, to gather the needed data. In anthropology, graduate fieldwork typically lasts at least one year. When I did my research on local dispute settlement in Ecuador, I spent a total of eleven months (over three separate periods) doing fieldwork. This, obviously, makes participant observation an expensive research method. Another limitation of participant observation is that some behaviors are quite difficult - if not dangerous or illegal - to get engaged in. Obvious examples would include drug trafficking and other criminal cultures. The utility of participant observation also depends on one's own personal characteristics - not everybody is comfortable in the role of participant. As DeWalt and DeWalt (2002, p. 30) conclude: 'Largely, the establishment of our own limits to participation depends greatly on our own background and the circumstances of the people we study. Our personal characteristics as individuals - our ethnic identity, class, sex or religion - will determine how we interact with and report on the people we are studying'. This final comment also refers to the subjective nature of the data that one gathers when participant observation is used.

Data collected through participant observation is subjective in nature. The researcher is constantly interfering with the situation or the subjects being observed. Subjectivity in sociolegal research, however, is not a bad thing; on the contrary, it is essential to preserving the quality of your data. Because the 
observer 'becomes a participant in what he observes' (DeWalt \& DeWalt, 2002, p. 24), he is able to attain special insight into the insider's point of view. But this 'special insight' can be understood correctly by your readers only if you are as open as possible about the way you conducted your participant observation. This means that the researcher needs to make his or her role and biases, and the degree of participation in the research, entirely explicit. In the book I published on my research in Ecuador, I wrote at least eight pages on the methodology I used, identifying my own biases as a researcher and discussing the ethical issues involved in my research (Simon Thomas, 2017, pp. 11-18).

\section{My personal experiences with participant observation - in the field and in the classroom}

My initial experiences with participant observation involved conducting legal anthropological fieldwork, first in Guatemala in 2006 (three months) and then in Ecuador during the years 2007, 2009, and 2010 (eleven months in total). In Guatemala, as part of my Bachelor's degree program in anthropology, I conducted research on two local courts in San Pedro and Comitancillo (both in the province of San Marcos). My research concerned how the mostly white or mestizo judges dealt with cases concerning local, indigenous (Maya) customary law (Simon Thomas, 2006). Part of my preparation for this work consisted of learning to read and speak Spanish. And, of course, I read as much as possible about the Guatemalan legal and political context and about customary law. Once in the field, I was lucky that the woman from whom I rented a room had a cousin who worked as a judge at the court of San Pedro. After I explained to that judge what my research was about, she gave me permission to conduct participant observation (including access to files and the possibility of conducting semi-structured interviews) at the court. During the weekly staff meeting on the first day of my work, she introduced me to her colleagues and encouraged them to assist me in my work. I felt truly fortunate to obtain such quick access to the court. I also eventually appreciated the fact that people are willing to open up to you about the work they do. Once in the field, I learned that building rapport and getting accepted was not as hard as I had thought it would be, though it did take some time to achieve.

A similar thing happened to me when I did my research on local dispute settlement in a situation of de jure legal pluralism in Ecuador. The first time I went there was in 2007 during a three-month period of research on legal pluralism and inter-legality for my Master's degree program in Latin American Studies (Simon Thomas, 2009). I conducted research in archives in Quito (the capital of Ecuador) and at the court in Latacunga (the capital of Cotopaxi province). There I was introduced around by a lawyer with whom I had made contact earlier because he was known as the local expert on indigenous Kichwa customary law. Here too, once I got formal access to the court, I gained acceptance relatively soon. It was during this research that I realized how much time it takes to take proper field notes. During 
my archival research, I made numerous notes in my notebook, which I wrote out during the evening in field notes. During my research at the court I was able to make rough notes, draw pictures of social settings, make copies of relevant files, and sometimes even take photographs. During my observations and interviews (some of which I recorded) I used previously drafted topic lists. But all these jottings, rough notes, recordings, etc. had to be written down in field notes as well. This a very time-consuming task but is absolutely necessary as without proper field notes you do not have adequate data. As DeWalt and DeWalt (2002, p. 141) observe: '...the writing of field notes is virtually the only way for the researcher to record the observation of day-to-day events and behavior, overheard conversations, and informal interviews, which are the primary materials of participant observation'. ${ }^{2}$ Only these kinds of field notes are considered data that can later be analyzed. I improved in participating, observing, interviewing, and taking field notes during my $\mathrm{PhD}$ research on local dispute settlement and legal pluralism, which involved fieldwork in 2009 (two months) and 2010 (six months) in Quito, Latacunga, and the remote indigenous village of Zumbahua, in the Andean highlands, where I spent a lot of time at the office of the local teniente politico, a kind of justice of the peace (Simon Thomas, 2017).

The education I got on the 'art of participant observation' stems from two courses on methodology in anthropological research, ${ }^{3}$ from another course that was dedicated to Bachelor-level fieldwork, ${ }^{4}$ all taught at Utrecht University, and from an additional course on methodology in my Master's program at CEDLA (Centre for Education and Documentation on Latin America) in Amsterdam. ${ }^{5}$ After I graduated, I started as a junior lecturer in the Department of Cultural Anthropology at Utrecht University, where I taught both the methodology courses and the Bachelor's fieldwork course. In all these courses, we taught participant observation (i.e. as one of the methods of doing empirical, qualitative research) through structured in-class exercises and discussions. Many of the written sources I refer to in this article are derived from those courses. An interesting aspect of the Bachelor's-level fieldwork course is that students had to report three times from the field to their supervisor - first after a couple of weeks regarding initial entrance into the field, during the second half regarding the actual fieldwork and participant observation, and then during the final week with a provisional analysis of the field notes. During their stay in the research setting, students could

2 DeWalt \& DeWalt (2002, pp. 141-162) distinguish different kinds of field notes: jot notes ('words, phrases, or sentences that are recorded during the course of a day's events primarily as aids to memory' (2010, p. 144)), expanded field notes - field notes proper, methodological notes, diaries and journals, logs, head notes, and analytical notes.

3 'Methoden \& Technieken', Bachelor year 1 course (coordination: Dr. Jan Kooistra) and 'Kwalitatieve onderzoeksmethoden: achtergronden en toepassingen', Bachelor's program year 3 course (coordination dr. Geert Mommersteeg).

4 'Bachelor project', Bachelor's program year 3 course (coordination: Dr. Marie-Louise Glebbeek).

5 'Voorbereiding scriptieonderzoek in Latijns-Amerika', Master's course (Coordination: Dr. Pitou van Dijck and Dr. Arij Ouweneel). 
e-mail, Skype, or call their supervisor with questions, concerns, etc. Although the students were far away (most students did their fieldwork abroad), we teachers were able to supervise our students' practice of skills in an interactive way - albeit from a distance.

I encountered a different way of teaching how to conduct fieldwork when I started working as a lecturer in the Sociology of Development and Change (SDC) group at Wageningen University in 2013. In the final semester of the second year of their study, SDC students enroll first in a course on methodology, ${ }^{6}$ in which they are taught the basics of empirical, qualitative (and, optionally, quantitative) research, during intensive workshops in which literature on methodology is discussed. This course was immediately followed by the Field Research Practicum, coordinated by Dr. Elisabet Rasch, during which students actually go into the field together with their teachers. The main objective of the Field Research Practicum is to expose students to the complete research process, from research design to actual fieldwork (two weeks in Roscommon, Ireland, or Devon, England) to the presentation of the research results. Each student completes the fieldwork assignment: conducting interviews, doing participant observation, and making field notes, while living with a host family. After this two-week period of doing fieldwork, the students return to Wageningen and write their research report within a week. ${ }^{7}$

The main task of the supervisors in this course is to guide the students through the insecurities of doing fieldwork. Supervisor-student interaction starts during the first workshop meeting of the course, when the students write their research proposal. During the course, these interactions become part of the teachers' and students' everyday life and provide a way of sharing experiences. This student-supervisor relationship evolves when students and teachers are in the field at the same time, through individual field visits, e-mail contact, and phone calls. A kind of rapport between student and teacher is developed, which is necessary to be able to discuss more personal issues that arise during fieldwork, such as homesickness, shyness, anxiety, or even depression. In the words of one author describing students' initial fieldwork experiences (Cohen, Falzon \& Mittelmeijer, 2001): 'no matter how well one can be prepared in theory, once in the field, you will find yourself.' This last element is called 'reflectiveness'. Students are challenged to reflect on their fieldwork and their own positionality in the field during their talks with the supervisor in the field, in their midterm report and in their final report (Rasch et al., forthcoming). Although good fieldwork preparation is

6 'Methods, Techniques and Data Analysis for Field Research', Bachelor's year 2 course (Coordination: Dr. Elisabet Rasch and Dr. Marit van den Berg).

7 The learning outcomes of this course are specified in the Course Guide: 1) design field research and formulate research questions; 2) build rapport in a fieldwork situation; 3) use various exploratory research techniques; 4) cope with unexpected fieldwork situations; 5) write down field notes and organize fieldwork material; 6) reflect on methods and role as a researcher in the field; 7) systematically analyze fieldwork material; and 8) write a research report. 
important (Emerson, Fretz \& Shaw, 2011; Hammersley \& Atkinson, 2007; Madden, 2010), the students are also coached to be able to handle 'the unexpected', be flexible, and rely on the fact that some things depend on serendipity. It is during this Field Research Practicum that I encountered the benefits of pairing exercises and fieldwork, as described by Levine et al. (1989, p. 40). It was during the course on methodology, however, that I first experienced the important role that a game can play in the teaching process. During the week in which we discussed participant observation, we let the students play 'musical chairs'.

\section{How to teach participant observation - musical chairs}

Musical chairs is a game in which a number of chairs, one fewer than the number of players, are arranged in a circle facing outward, with the players standing just outside the arranged chairs. Usually, music is played while the players in the circle walk in unison around the chairs. When the music stops, each player attempts to sit down in one of the chairs. The player who is left without a chair is eliminated from the game. One chair is then removed to ensure that there will always be one fewer chair than there are players. The music resumes and the cycle repeats until there is only one player left in the game, who is the winner. ${ }^{8}$ I will now describe the way I use musical chairs in class for the purpose of teaching the unexpected difficulties of conducting participant observation.

As for the preparation, I rearrange the classroom before students enter. I put all tables aside and arrange the chairs facing outwards in a circle. I set two chairs aside for the two students I will ask to volunteer as observers. I play some music (my favorite is the song 'Happy' by Pharrell Williams). I do not tell my students beforehand what will happen in this class. I also do not tell them anything when they enter the class and ask questions. As soon as they enter the classroom, they notice the different arrangement of the furniture and hear the music, but clearly do not know how to react. Most of them put their bags on the table and then stand and wait. They giggle a lot and make jokes about what they expect to happen next, but none of them seem to be really comfortable with the situation. As soon as everybody is in class, I ask for two volunteers. Once the volunteers are seated in their chairs, I start to explain what I want the class to do. I tell them to play musical chairs, and I ask the two volunteers to observe the game and to make notes on what they see in order to describe afterwards what they observed their peers do. Once we know for sure that the number of chairs in the circle is one less than the number of playing students, I turn up the volume of the music. Then the game starts. 
Everybody knows how to play musical chairs, so the students are immediately engaged in the game. At a certain moment during the turning on and off of the music, I open a door or a window for a couple of minutes, but no one seems to notice. The greater the number of students in the class, the longer it takes to finish the game, and as the final round is nearing, the players in the game tend to become more enthusiastic. Everyone typically laughs loudly at the end, when only the one 'winner' is left seated. I then ask the students to sit and take notes about what they just experienced as participants. After a couple of minutes, I tell them to stop writing, and I ask the two observers to tell us what they have noticed. They usually come up with a chronological record of what they had just seen. I continue to ask the observers to note anything that is particularly remarkable, and, once the observers have completed their account, I ask the participants in the game what they noticed. Their record of the game represents an 'insider's account'. And it always strikes me how much of the students' personal feelings are reflected in their accounts. Here are examples of typical comments: 'First I felt a bit ashamed, having to play a game'; 'I felt miserable to be the first to leave the game'; and 'Once I knew I could win, I really became enthusiastic'. I then ask if anyone had noticed that the door (or window) had been open for a couple of minutes. No one had - not even the two observers. I then take the students' accounts of what has transpired as the starting point for analysis and discussion.

There are a couple of things I want my students to consider as 'learning moments'. The first of these is the difference in the accounts of the two observers, on the one hand, and the group of participants, on the other. I use this example to explain the difference between Spradley's (1980) moderate participation (the two observers) and complete participation (the group of players) and what this means for the kind of data you gather. The observers' recording is more often a chronological account of what happens in the setting, recounting who did or said what at discrete moments in time. Their accounts of events are obviously more complete than those of the participants, especially as regards the actions and positions of the students in the class and the activity that took place. Most of the observers fail, however, when it comes to providing details of the physical space itself. Sometimes, they defend themselves by claiming that I had not been specific regarding what exactly they needed to observe. That gives me the opportunity to stress the importance of a good research question as a useful tool for focusing observations. The accounts of the participants, on the other hand, provide more 'in-depth' details of what it was like to be in the game.

The awareness of these differences between an outsider's view and an insider's view is considered very helpful by most of my students. We then discuss the difficulties of participating and observing at the same time. Students become aware of how much they need to train themselves to become participants and observers simultaneously. And they attain insight into the effects of using different degrees of participation. The failure to notice the opened door or window is used to point out the difficulty of both determining what to observe and paying attention to 
detail. I also make reference to a selective attention test: a video where a gorilla suddenly shows up among a group of six people - three in white shirts and three in black shirts - who are passing a basketball around. Viewers are asked to count the passing of the ball by the people in the white shirts. At a certain point during the video, the gorilla appears. The striking thing here is that when asked afterwards, fifty percent of the people watching the video had not noticed the gorilla (Simons \& Chabris, 1999). ${ }^{9}$

I then usually give my students more information regarding participant observation. Basically, I explain to them - with the aid of a short PowerPoint presentation - what is dealt with above in Section 2. The key elements of participant observation can be easily illustrated with a reference to the game they just played. The difference between 'observing' and 'participant observing' now becomes evident to them, and so do the different degrees of participant observation. The different stages one needs to go through cannot be completely illustrated by this exercise, but the emotions that are involved in doing participant observation can be easily identified. We discuss the students' uneasiness at the beginning of the class, in regard to their not knowing how to react to an unexpected situation. This contrived situation is obviously analogous to what they will experience during their initial days of actual fieldwork. And, finally, we analyze their emotional status during the game (disappointment or enthusiasm) and reflect on it. I can then explain that this reflectiveness is crucial for the quality of the collected empirical and qualitative data. We usually end with a discussion on how one's own biases 'colour' the data. It is at that point that I comment on the subjectivity of empirical data and the need to be as open as possible about one's biases when reporting data that has been collected. To this end I stress the importance of taking good notes and talk about the difference among the various kinds of notes that students will need to take during their fieldwork.

\section{Conclusion}

This article is written with two audiences in mind: students and teachers. Its aim is to fill the gap on how to conduct - and how to teach - participant observation as a method of empirical and qualitative legal research. With regard to the first aim, Section 2 on 'participant observation' serves as a basic introduction for the beginning sociolegal researcher who is about to become a participating observer for the first time. That introduction on participant observation also serves as a useful reference and guide for those who teach qualitative research methods in legal education and who are looking to enhance their knowledge and skills concerning participant observation. By elaborating on the experiment with musical

9 The Invisible Gorilla. (n.d.). The gorilla experiment. Retrieved from http://www.the invisiblegorilla.com/gorilla_experiment.html (last accessed 5 October 2018). Mack and Rock (1992) called this phenomenon 'inattentional blindness'. 
chairs in class in Section 4, this article provides a useful example of how to teach the basics of participant observation to law students.

The musical chairs game that I play in class, while not especially sophisticated, does help students vividly understand what participant observation is about. First of all, the part of this class during which I lecture (i.e. the part where I use a PowerPoint presentation) serves as a basic introduction to participant observation. The play itself serves as a 'real-life' example of the difference between observing and participating and of the difficulties encountered when one needs to participate and observe at the same time. The discussions in class are meant to highlight the importance of reflectiveness, the inevitable subjectivity of gathered data, and of taking good field notes. Of course, this two-hour class can in no way replace an initial real-life fieldwork experience or compare to actual participant observation. But it can be useful as an orientation to what real participant observation is about. Without exception, the musical chairs experiment is highly evaluated by my students - it provides a real 'eye-opener' for them. And it is also a lot of fun.

\section{References}

Baarda, D. B., De Goede, M. P. M. \& Van der Meer-Middelburg, A. G. E. (1996). Open interviewen. Praktische handleiding voor het voorbereiden en afnemen van open interviews. Groningen: Stenfert Kroese.

Cane, P. \& Kritzer, H. M. (Eds.). (2010). The Oxford handbook of empirical legal research. Oxford: Oxford University Press.

Cohen, M., Falzon, C. \& Mittelmeijer, M. (Eds.). (2001). Veldwerk in uitvoering. Verhalen van antropologen in spe. Amsterdam: Aksant.

Curry-Sumner, I., Kirsten, F., Van der Linden-Smith, T. \& Tigchelaar, J. (2010). Research Skills. Instruction for Lawyers. Nijmegen: Ars Aequi Libri.

DeWalt, K. M. \& DeWalt, B. R. (2002). Participant observation: A guide for fieldworkers. Walnut Creek: Altimara Press.

Doornbos, N. (2014). Observeren in de rechtszaal. Recht en Methode in Onderzoek en Onderwijs, 2014(3). doi:10.5553/REM/.000002.

Emerson, R. M., Fretz, R. I. \& Shaw, L. L. (2011). Writing ethnographic fieldnotes. Chicago: University of Chicago Press.

Friedrichs, J. \& Lüdtke, H. (1975). Participant observation. Theory and practice. Westmead: Saxon House.

Hammersley, M. \& Atkinson, P. (2007). Ethnography. Principles in practice. London and New York: Routledge.

Holvast, N. (2017). In the shadow of the judge. The involvement of judicial assistants in Dutch district courts. The Hague: Eleven International Publishing.

Jackson, J. E. (1990). I am a fieldnote: Fieldnotes as a symbol of professional identity. In R. Sanjek (Ed.). Fieldnotes: The makings of anthropology (pp. 3-33). Ithaca: Cornell University Press.

Jorgensen, D. L. (1989). Participant observation. A methodology for human studies. Newbury Park, London and New Delhi: SAGE Publications.

Kottak, C. P. (2002). Anthropology. The exploration of human diversity. Boston: McGraw-Hill. 
Levine, H. G., Gallimore, R., Weisner, T. S. \& Turner, J. L. (1980). Teaching participantobservation research methods: A skills-building approach. Anthropology \& Education Quarterly, 11(1), 38-54.

Lindeman, J. (2017) Officieren van justitie in de 21e eeuw. Een verslag van participerend observatie-onderzoek naar de taakopvatting en taakinvulling van officieren van justitie. Den Haag: Boom juridisch.

Mack, A. \& Rock, I. (1992). Inattentional blindness. Cambridge: MIT Press.

Madden, R. (2010). Being Ethnographic. A guide to the theory and practice of ethnography. London, Thousand Oaks, New Delhi and Singapore: SAGE Publications.

Malinowski, B. (1985 [1926]). Crime and custom in savage society. Totowa: Helix Books.

Moore, H. L. \& Sanders T. (Eds.), Anthropology in theory. Issues in Epistemology. Malden, Oxford and Carlton: Blackwell Publishing.

Rabinow, P. (2007). Reflections on fieldwork in Morocco. London, Berkeley and Los Angeles: University of California Press.

Rasch, E. D., Simon Thomas, M., Cremers, G. \& Verschuuren, B. (forthcoming). 'It's not in the course guide!' Learning how to do fieldwork. Anthropology and Education Quarterly.

Sanjek, R. (1990). Fieldnotes: The makings of anthropology. Ithaca: Cornell University Press.

Simon Thomas, M. (2006). De drempel van de rechtbank. Een onderzoek naar gewoonterecht in de officiële rechtspraktijk in San Marcos, Guatemala [Bachelor's thesis, Utrecht University].

Simon Thomas, M. (2009). Legal pluralism and interlegality in Ecuador. The La Cocha murder case. Amsterdam: CEDLA.

Simon Thomas, M. (2017). The challenge of legal pluralism. Local dispute settlement and the Indian-state relationship in Ecuador. London and New York: Routledge.

Simons, D. J. \& Chabris, C. F. (1999). Gorillas in our midst: Sustained inattentional blindness for dynamic events. Perception, 2, 1059-1074.

Spradley, J. P. (1980). Participant observation. New York: Holt, Rinehart and Winston.

Toren, C. (2006). Introduction to mind, materiality and history. In H. L. Moore \& T. Sanders (Eds.). Anthropology in theory. Issues in Epistemology (pp. 204-219). Malden, Oxford and Carlton: Blackwell Publishing.

Van Aeken, K. (2011). Law, sociology and anthropology. A liaison beginning endlessly. In B. Van Klink, B. \& S. Taekema (Eds.). Law and method (pp. 55-83). Tübingen: Mohr Siebeck.

Van Klink, B. \& Taekema, S. (Eds.) (2011). Law and method. Tübingen: Mohr Siebeck.

Van Rossum, W. (1998). Verschijnen voor de rechter. Hoe het hoort en het ritueel van Turkse verdachten in de rechtszaal. Amsterdam: Duizend \& Een.

Wallace, J. M. (1999). Special reflections from the field: Mentoring apprentice ethnographers through field schools. Anthropology and Education Quarterly, 30(2), 210-219.

Webley, L. (2010). Qualitative approaches to empirical legal research. In P. Kane \& H. M. Kritzer (Eds.). The Oxford handbook of empirical legal research (pp. 926-950). Oxford: Oxford University Press.

Zaitch, D., Mortelmans, D. \& Decorte, T. (2010). Participerende observatie in de criminologie. In T. Decorte \& D. Zaitch (Eds.). Kwalitatieve methoden en technieken in de criminologie (pp. 261-314). Leuven: Uitgeverij Acco. 